\title{
THE APPLICATION OF MORPHOSTRUCTURAL ANALYSIS AND ITS VALIDATION BY COMPARISON WITH DOCUMENTED FAULTS WITHIN THE ZLATÉ HORY ORE DISTRICT (THE NORTHEASTERN PART OF THE BOHEMIAN MASSIF)
}

\author{
Jan JELÍNEK ${ }^{1,2)}$ *, František STANĚK ${ }^{1)}$, Jan THOMAS ${ }^{2)}$, \\ Tomáš DANĚK ${ }^{1,2)}$ and Jiř́ MALIŠ ${ }^{1,2)}$ \\ 1) Institute of Geological Engineering, Faculty of Mining and Geology, Vysoká škola báňská - Technical \\ University of Ostrava, 17. listopadu 15/2172, Ostrava-Poruba, 708 33, Czech Republic \\ 2) Institute of Clean Technologies for Mining and Utilization of Raw Materials for Energy Use, Faculty of Mining \\ and Geology, Vysoká škola báňská - Technical University of Ostrava, 17. listopadu 15/2172, Ostrava-Poruba, \\ 708 33, Czech Republic \\ *Corresponding author's e-mail: jan.jelinek@vsb.cz
}

(Received July 2012, accepted November 2012)

\begin{abstract}
The goal of this study is to determine the validity of morpholineaments network that was inferred based on morphostructural analysis of digital elevation model (DEM), by crosschecking with documented faults. The test field has been spread over the exploitation areas in the Zlaté Hory ore district. Various morphometric analyses such as slope, aspect, first directional derivative, gradient operator, combination of altitude and shaded relief, were chosen as particular tools of the morphostructural analysis. The results of each analysis were compared with the results of structural-tectonic mapping. The inferred morpholineaments network was compared with mining maps of the scale 1:500, which provide detailed information about tectonic deformation of rock massif in the area of interest and were used to image fault traces on the surface. The validity of inferred morpholineaments network was determined by authorized software SROV_TEKT, developed by the authors. The morpholineaments network resulting from the morphostructural analysis and tested by this software overlaps at $83 \%$ of the documented main faults in the mines.
\end{abstract}

KEYWORDS: tectonic geomorphology, morpholineament, morphometry, digital elevation model, structural analysis

\section{INTRODUCTION}

The morphostructural analysis (MSA) offers a various possibilities in different disciplines of geoscience. Its results has already been commonly applied in tectonic and geomorphological studies of several areas (Caiazzo et al., 2006; Cotilla et al., 2007; D'Alessandro et al., 2008; Grohmann et al., 2007; Jelínek et al., 2009, 2011; Jordan, 2003; Kukowski et al., 2008; Masoud, Koike, 2011; Miliaresis, 2001; Minár et al., 2011; Mumipour, Nejad, 2011; Norini et al., 2004; Rehak et al., 2008; Seta et al., 2008; Sung, Chen, 2004; Zuchiewicz, 2009; etc.). The established morphological lineament network forms a study foundation of for example: neo-tectonic activities of areas of interest (Arzhannikova et al., 2011; Delcaillau et al., 2010; Gioia et al., 2011; Ruszkiczay-Rüdiger et al., 2009), study of the river network genesis (Maroukian et al., 2008; Štěpančíková et al., 2008; Zuchiewicz, 1998, 2011), study of landslide hazard (Cadoppi et al., 2007; Kokkalas, Koukouvelas, 2005; Pánek et al., 2009; Marschalko et al., 2011), etc.. In the field of applied geology, the MSA is frequently used in studies of tectonic deformation of the rock massif.
The aim of this study is to evaluate the reliability of the inferred morpholineaments network compared with documented faults of rock massif. The morpholineaments network is constructed manually by selected methods of MSA from digital elevation models (DEM). The established morpholineaments are compared with tectonic deformations verified in the mines. The available geological maps of the scale 1:50 000 are not detailed and precise enough. Fault zones indicated in these maps are usually only assumed (see Fig. 1). Only few of them were actually observed by field mapping.

The area of study is the ore district of Zlaté Hory located in the north-eastern part of the Bohemian Massif. Due to occurrence of significant mineral resources in the deposit, a very detailed mining geological survey was carried out in this region. Thus, the tectonic deformation of the whole deposit is well documented. The data obtained from the mining exploration and mining itself provides us with more accurate and detailed information than the uncovered geologic maps. 


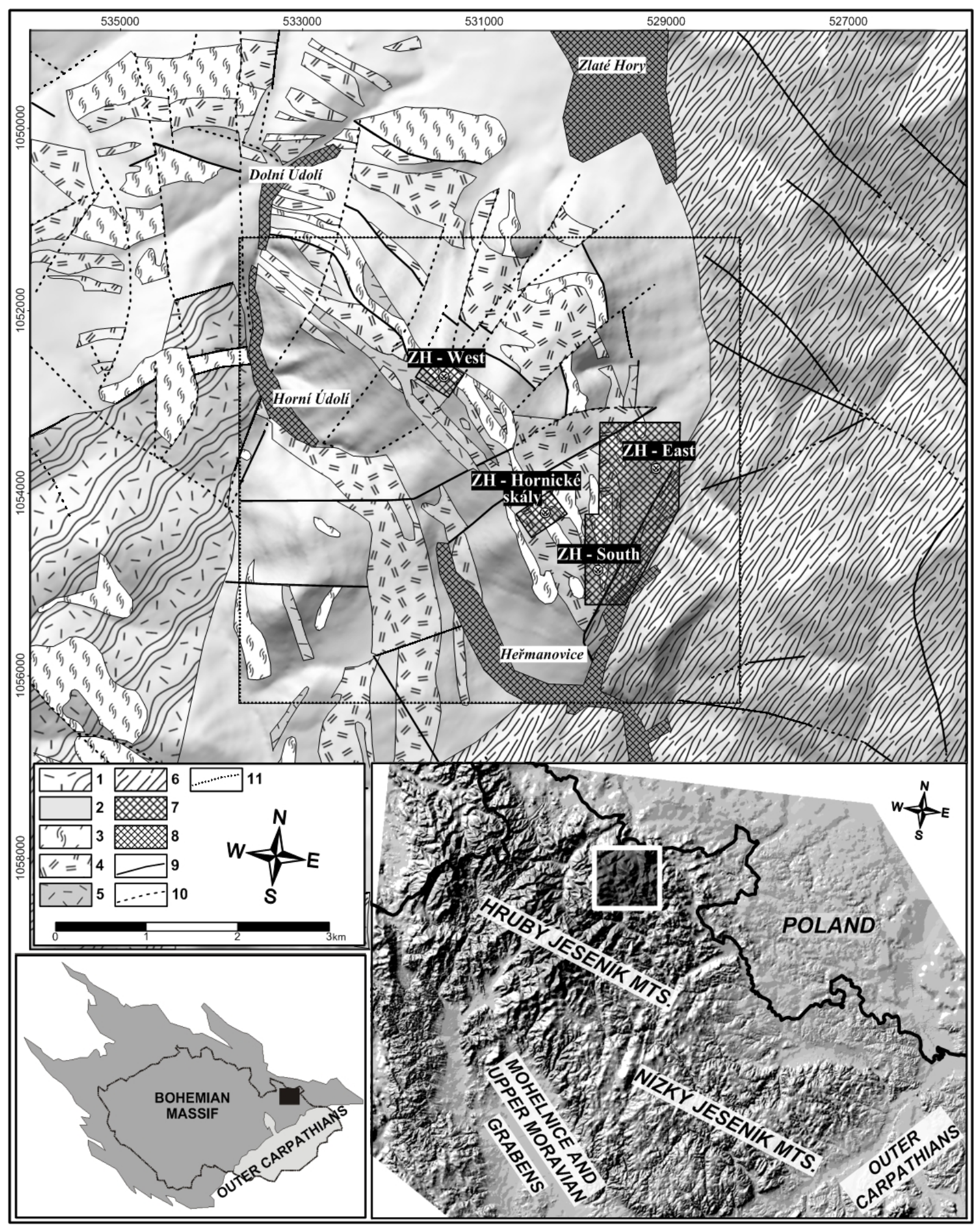

Fig. 1 Geological situation and localization of the Zlaté Hory ore district. Geological map compiled and modified from geological map of the scale 1:50 000 .

Legend: 1 - biotitic and double-mica orthogneiss of Desen's arch; 2 - chlorite schists, phyllites and Eastern shists of Vrbno formation; 3 - quartzites; 4 - green schists and amphibolites of Vrbno formation; 5 - acid metavolcanites of Vrbno formation; 6 - lower carboniferous graywackes, claystones and siltstones of Andělská Hora formation; 7 - exploitation areas; 8 - municipalities; 9 - faults (see geological map 1:50 000); 10 - supposed faults (see geological map 1:50 000); 11 - detailed morphostructural analysis area border. 


\section{GEOLOGICAL BACKGROUND}

The Zlaté Hory ore district belongs to the Variscan orogenic system located on eastern margin of the Bohemian Massif, so-called Moravian-Silesian zone. The ore district is situated in the volcanosedimentary complex of strongly deformed and metamorphosed Devonian rocks belonging to the Vrbno Group, which is a cover unit of the Desná Group (Grygar and Kalenda, 1992). Both units belong to the eastern part of Silesicum. The core of the Desná Group comprises medium-grade to partly magmatic biotitic-rich banded gneiss, ophthalmitic to stromatitic migmatites and numerous amphibolite bodies (Schulmann and Gayer, 2000). The Devonian cover, the Vrbno Group, consists of quartzites, micaschists and metavolcanic rocks (Fig. 1). The eastern and northern parts of the Devonian cover are formed by basal quartzites, metaconglomerates, metapelites, marbles and acid to basic metavolcanic rocks (Schulmann and Gayer, 2000). The Vrbno Group emerges on western flank of the area of interest (Fig. 1).

Grygar and Kalenda (1992) describe the structural-tectonic pattern of the ore district as a complex composite anticline with imbricated overlapping evolution. The anticlinorium axis passes through the center of the Zlaté Hory ore district and is arched from SSE in the south to NW-WNW in the northern area. The composite anticline is westward overturned and becomes a simple anticline in the SSE direction (Grygar, 1987). In the east, the Vrbno Group is detached by westward vagrancy Andělská hora thrust (see Fig. 1) from flysch sequences of LowerCarboniferous formation of Andělská hora (Grygar, 1987). Along the northern border of the district, the crystalline rocks of Vrbno formation are covered by massive formations of quaternary, fluvioglacial sediments (Večeřa, 1999).

The complex Silesicum tectonic structure is linked to the Variscan polyphase oblisque collision of Brunovistulian and Lugicum. During this collision Silesicum nappes moved over the Devonian synriftic basin (Schulmann and Gayer, 2000). The characteristic deformation system of the Silesicum crystalline complex and its Devonian rocks cover (Vrbno formation) is the Variscan deformation phases $\mathrm{D}_{2}$ and $\mathrm{D}_{3}$ (Schulmann and Gayer, 2000). The most evident distinction between these two systems is best observed in the Vrbno area, especially in the structure of Zlaté Hory district (Grygar, 2001). A very tight similarity all linear systems in direction from ENE up to NNE with major south-east asymmetry is specific to these deformations (Grygar, 1992). According to Rambousek et al. (2004), these deformation are linked to the origin of folds $F_{2}$ (Orel, 1975), faulted overfolds and shear fractures. The overfolds are abrupt on east of Vrbno formation, flatter towards to west and converge to flatbed nappe (Grygar, 1992). The Grygar and Vavro (1995) interpret this feature as a result of dextral transpressive kinematics overlapping orientated along the ESE-WSW direction (final position after clockwise rotation). Due to general northern kinematics on the major sub-equatorially oriented Variscan thrust front, these thrusts appear as back-thrusts.

Final Variscan orogenic phase is associated with a change of deformation mode. The compression stress in Silesicum was NNW-SSE oriented. An extrusion of the Vrbno tectonic unit of allogenous accretionary wedge took place, associated to the continued subduction of Brunovistulicum. The zone was influenced by transpressional folding and shearing (Schulmann and Gayer, 2000). Third generation folds $F_{3}$, as well as deformations represented by series of shear zones were formed, affecting the lithology of Devonian and Culm basin.

\section{METHODOLOGY}

The goal of this study is to determine the validity of morpholineaments network that was inferred based on the morphostructural analysis of digital elevation model (DEM), by crosschecking with documented faults (Fig. 2). Thus, we created testing morpholineaments network by applying selected morphometric methods of MSA. Widely used morphometric analyses of DEM available in software such as Surfer, ArcGIS, Grass, etc. are as follows: slope, aspect, altitude and diverse analyses of the drainage network (Formento-Trigilio et al., 2002; Kukowski et al., 2001; Scheidegger, 2001; etc.). The first and second directional derivatives have also been used (Jayko, 1997; Jordan et al., 2003; Pánek, 2004). The plan curvature, profile curvature and gradient operator are also newly employed. In this study, the MSA methods of slope, aspect, first directional derivative gradient operator and combination of altitude and shaded relief were used. The DEM study was focused to landforms which are potentially related to tectonics such as the foot or trace of rectilinear slopes, the occurrence of parallel valleys, the shape of drainage network etc., see the criteria defined Ahnert (1998), Bloom (1998), Demek (1987) and Ritter et al. (2002). Because the genesis of some morpholineaments may be linked to different geological processes such as selective erosion of different lithological rock units or joint systems (Ritter et al., 2002), morpholineaments interpretations were compared with the results of the structural analysis (Fig. 3).

Verification of potential tectonic origin of the inferred morpholineaments was carried out by comparison with faults documented in mines. The testing was carried out in selected exploitation areas of the Zlaté Hory ore district (ZH - West; ZH Hornické skály; ZH - South; ZH - East), see Figure 1. The criterion for selection of the exploitation area was ample structure mining records and existence of underground structural maps. For the following areas $\mathrm{ZH}$ - East and $\mathrm{ZH}$ - South, maps from seven mining levels ranging from 50 to $80 \mathrm{~m}$ below the surface were 
冈

Fig. 2 Sketch showing the methodology of morpholineaments interpretation using selected morphometric methods and structural analysis. 


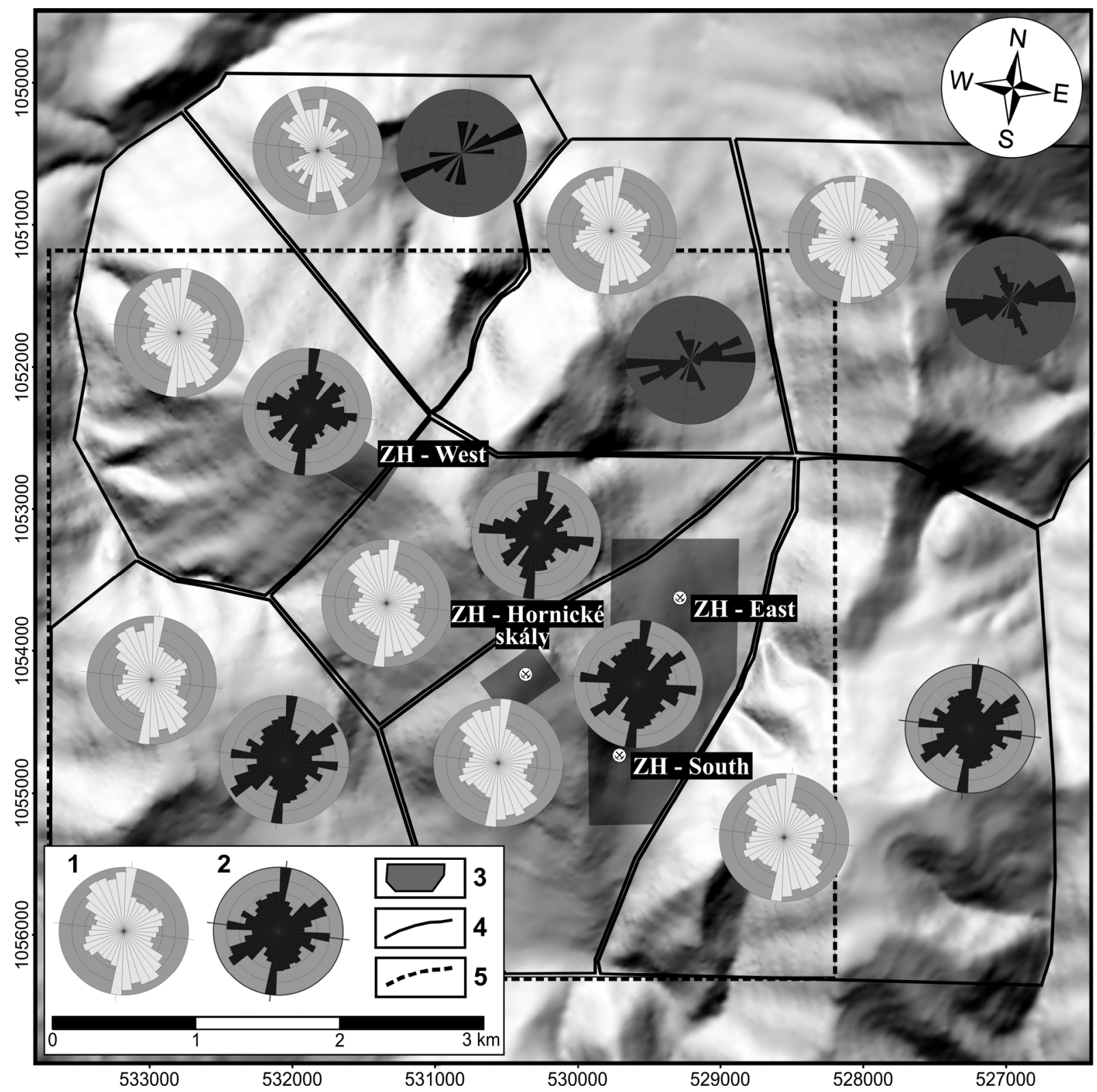

Fig. 3 Digital elevation model of wider surrounding of the Zlaté Hory ore district with rose diagrams.

Legend: 1 - rose diagram of joints; 2 - rose diagram of faults; 3 - exploitation areas; 4 - polygon's border of individually analyzed sub-regions by SA ; 5 - area processed in detail by MSA.

available. The studied maps at the scale of 1:500 display very detailed information. An emphasis within the comparative analysis was placed on dislocations which have been correlated for the same level but in different mining works. These important dislocations were vertically correlated on the base of structural records within the individual levels. A dense network of spatially dispersed structural data allowed us to display the significant faults reaching up to the surface (Fig. 4). Given the scale of the mine maps and structural records (analyzed faults dip), the approximated deviation of particular faults identified on the surface lies in the interval of $10-20 \mathrm{~m}$.
In order to evaluate the mutual resemblance between the morpholineaments network and the network of faults identified in mines, specialized software called SROV TEKT* created by the authors was used (a detailed description of the functions of this software, including the possibility downloading can be found at http://geologie.vsb.cz/VaV). This software compared the individual interpreted morpholineaments with the set of all faults. All morpholineaments and faults were numbered. An area of assessment (buffer) was assigned to each fault. Considering the accuracy of the faults network in the tested exploitation areas, the buffer width was set to $20 \mathrm{~m}$.

* The software SROV_TEKT can be used to determine the validity of morpholineaments network created by any methodology. 
Table 1 Table of similarity of individual morpholineaments extending into fault buffer. Example of fault No. 20 .

Fault: No. 20 Lenght: $1102 \mathrm{~m}$ Azimuth: $24^{\circ}$

\begin{tabular}{|c|c|c|c|c|c|c|c|}
\hline \multicolumn{3}{|c|}{ Morpholineaments } & \multicolumn{5}{|c|}{ In-buffer } \\
\hline No. & LM & $\begin{array}{l}\text { Azimuth } \\
\text { (average) }\end{array}$ & $\begin{array}{l}\text { Azimuth } \\
\text { deviation }\end{array}$ & LMB & LMB/LM & $\begin{array}{l}\text { Average } \\
\text { distance }\end{array}$ & $\mathrm{LMB} / \mathrm{FL}$ \\
\hline & {$[\mathrm{m}]$} & {$\left[{ }^{\circ}\right]$} & {$\left[{ }^{\circ}\right]$} & {$[\mathrm{m}]$} & {$[\%]$} & {$[\mathrm{m}]$} & {$[\%]$} \\
\hline 7 & 1444 & 23 & 0 & 840 & 58 & 2 & 76 \\
\hline 9 & 130 & 87 & 64 & 17 & 13 & 3 & 3 \\
\hline 10 & 261 & 83 & 59 & 15 & 6 & 3 & 2 \\
\hline 11 & 65 & 85 & 61 & 42 & 64 & 3 & 7 \\
\hline 24 & 555 & 23 & 1 & 345 & 62 & 4 & 54 \\
\hline
\end{tabular}

Next, we examined how many morpholineaments extended into the area of assessment. For each morpholineament the following was then computed: the length (LM), the average azimuth (weighted against the lengths of each segment), the mean azimuth morpholineament deviation from the average fault azimuth, length of the morpholineament in buffer (LMB), the overall percentage of the morpholineament length in the buffer, the average distance from the actual fault and the percentage of the morphological lineament length in the buffer relative to the fault length (FL). This information is tabled for each fault in Table 1, which also lists all particular morpholineaments extending to the buffer. The most fault-consistent morpholineament was automatically marked on the basis of its maximal in-buffer length. In the selection of the most consistent morpholineament, an emphasis was placed on the average azimuth deviation, the average distance from the fault and especially on the morphological lineament in-buffer length. Because some morpholineaments were common to more faults due to the denser faults network, it was necessary to qualify the selected morpholineaments visually as well. The visual interpretation was aimed at assessing the azimuth deviation and average distance.

Chosen morpholineaments were grouped into one table together with their identified parameters (Table 2). Next, the final evaluation of exactitude of the whole morpholineaments network was carried out, based on the average percentage length of covering all the fault buffers by morpholineaments.

\subsection{ANALYSIS OF MORPHOLINEAMENTS}

The morphostructural analysis was carried out in wider surroundings of the exploitation area sections: Zlaté Hory - West, Zlaté Hory - Hornické skály, Zlaté Hory - South and Zlaté Hory - East (Fig. 1). The DEM for this region was created with grid resolution $25 \times 25 \mathrm{~m}$ and based on DMU25 database. The accuracy of the input data corresponds to the accuracy of contours on the topographic maps of scale 1:25 000. For the exploitation areas, it was necessary to make more precise models (grid $10 \times 10 \mathrm{~m}$ ). Therefore the inputs were supplemented by points from topographic maps of scale 1:10 000. Sampling was carried out with regard to the interpolation method used for the computing of model (Jelínek et al., 2009). The selection of the interpolation method was accomplished by using the method of cross validation. The procedure of appropriateness testing of interpolation methods followed the rules established by Staněk et al. (2008). The impact of anisotropy on the relief modeling is detailed in the work by Jelínek (2004). The complied DEM displays a large amount of morphological details, which highlight terrain discontinuities.

Interpretation of morpholineaments was executed in three phases (Fig. 2). In the first phase, the networks of linear objects (morpholineaments) were created based on interpretation of the models inferred from individual DEM morphometric methods (models of terrain slope, terrain aspect, first directional derivative, gradient operator and combination of altitude and shaded relief). The morpholineaments were interpreted by a qualified estimate. The minimum length of morpholineament was set at $400 \mathrm{~m}$ (in selected sub-areas at $200 \mathrm{~m}$ ). For identification of morpholineaments procedures defined by Demek (1987) were used. These procedures were applied especially when analyzing the model of altitude and model of shaded relief. When analyzing the models of terrain aspect, gradient operator and terrain slope linear interface between different classes of values (Jayko, 1997) were searched. For the analysis of the slope these classes were defined by Ahnert (1998), Bloom (1998) and Demek (1987). The model of directional derivatives was interpreted according to the principles that were determined by Jordan (2003). Due to the fact that each method reflects different relief parameter, there is no absolute consensus of created networks. In many 


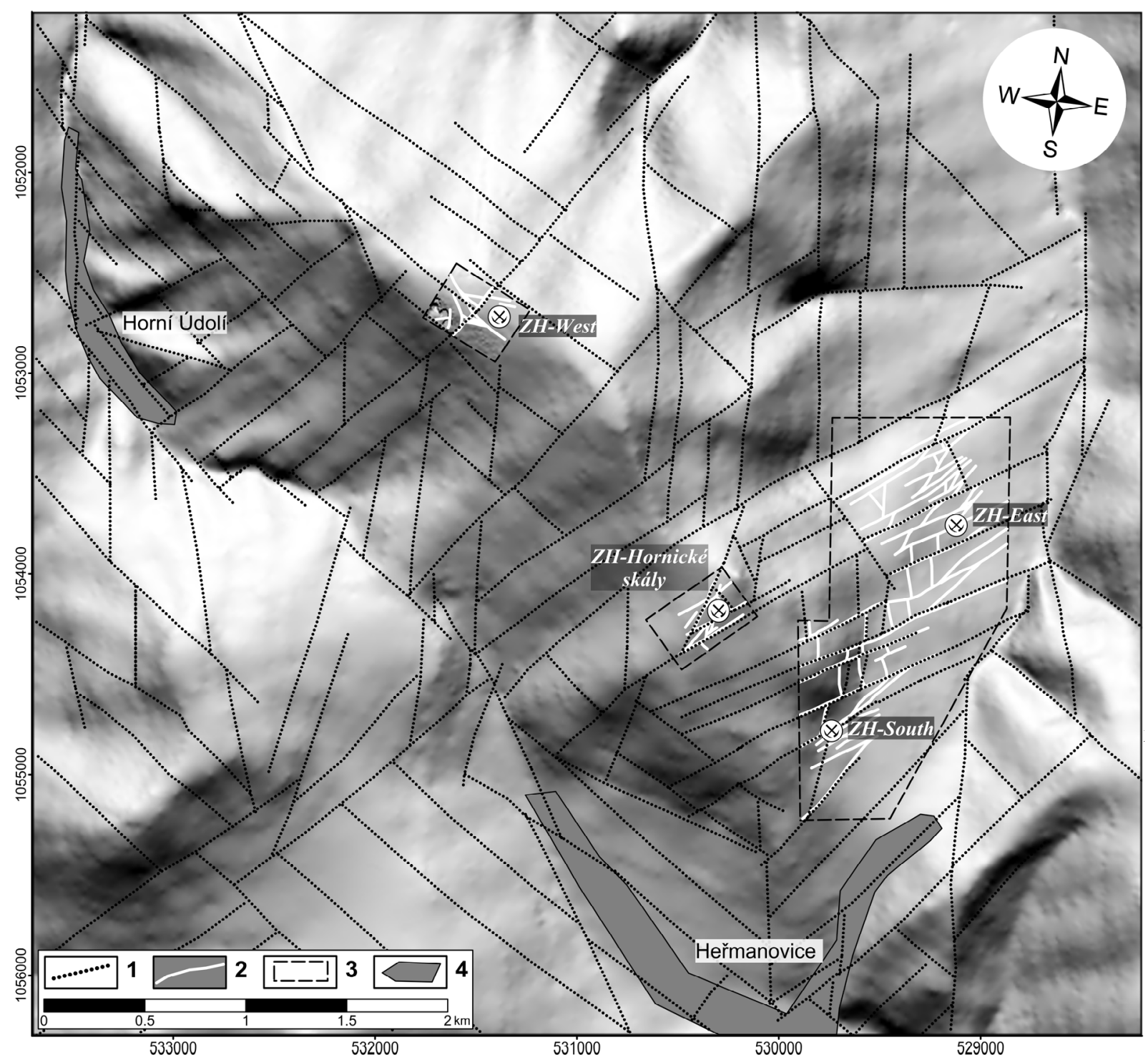

Fig. 4 Digital elevation model (shaded relief) of the area of interest with resulting morpholineaments network created by this methodology see Fig. 2 .

Legend: 1 - morpholineaments; 2 - confirmed faults; 3 - exploitation areas; 4 - municipalities.

places, the directions of identified morpholineaments correspond to each other, but their exact placement is not identical. In the second phase morpholineaments interpreted by just a single method were verified.

During the third phase, the morpholineaments acquired by using different methods were compared with the results of structural analysis. The task was to determine whether each of the interpreted morpholineament, is possible to be supported by found direction of some brittle failure. For every proven morpholineament it was then necessary to determine whether its presence in the landscape relief is subject to endogenous or exogenous processes, i.e. whether it is a fault or joint zone sculpted by selective erosion or lithological interface. This study requires the advanced knowledge of regional tectonic and morphological evolution, the nature of the fault networks and the spatial progression of the main fault zones. Therefore, those inferred morpholineaments whose presence was not confirmed by structural analysis of brittle failure in bedrock massif were excluded.

\subsection{STRUCTURAL ANALYSIS OF THE ZLATÉ HORY ORE DISTRICT}

The structural analysis (SA) of the study area was mainly focused on brittle deformation of the bedrock such as faults and joint systems. The results are primarily based on the data from field mapping and mining database of structural measurements. Accordingly with the lithological, structural and geomorphologic similarities, the region was divided into sub-regions. Faults and joints rosette diagrams were created especially for these sub-regions (Fig. 3). 
All the structural data were compiled within the software system called RUZDIA, which was created by the authors (a detailed description of the functions of this software, including the download link can be found at http://geologie.vsb.cz/VaV). This system depicts structural analyses results directly into the chosen coordinate system of the map output. Simultaneously, it enables to distinguish the rosette diagrams accordingly to their degree of credibility. The degree of credibility was established for joint systems for number of measurements between 1-50 (black rosette diagrams net - lowest credibility), 51100 (medium gray - medium credibility) and 101 or more (light gray - highest credibility). In the case of faults, the degree of credibility was established to 1-20, 21-50 and more than 51 measurements.

The credibility issue of the diagrams of the faults appeared in the northern sub-regions only, where the number of records dropped down to 50. The reason for this fact was a small incidence of the faults within the investigated outcrops. Moreover, many faults were not characterized with sufficient reliability. The strike or the sense of movement on the fault was not often indicated at all. For these reasons the paleostress analysis was not carried out, since it would not show sufficiently accurate results.

\section{STRUCTURAL INTERPRETATION OF MORPHOLINEAMENTS}

The inferred morpholineaments network exhibits the major direction NE-SW. The morpholineaments of this direction cut through the morpholineaments of other directions. The rose diagrams of joint systems and faults support this fact its existence (Fig. 3). There, it has appeared as statistically the second and the third most important maximum. Schulmann a Gayer (2000) consider the origin of this brittle failures system as from final phase of Variscan orogeny. In this phase of orogeny, the major compressive stress was placed in the direction NNWSSE. Under the brittle-ductile state, the uplift of the area formed, the youngest fold system with cleavage oriented NE-SW (Grygar, 1992). This cleavage direction is also confirmed by rose diagrams of joint systems, which are difficult to be distinguished from cleavage in the field, especially on quartzite outcrops. Schulmann and Gayer (2000) consider the formation of dextral shear zones oriented NE-SW as a result of this orogeny. Also rose diagrams of joint systems (Fig. 3 - second-rated maximum), and the faults observed in mines (Fig. 4) show the NE-SW direction as an important one. The dip of these faults varies around $90^{\circ}$.

During the same phase $\left(\mathrm{D}_{3}\right)$ of Variscan orogeny, within the same compressive stress, the brittle deformation orientation NW-SE was created (Schulmann and Gayer, 2000). The second most important system of morpholineaments corresponds to these brittle deformations. Rose diagrams of joint systems show this direction as the most dominant, together with the system NNW-SSE (Fig. 3). On the other hand, the rose diagrams of faults place this system mostly on the fourth place of occurrence. Schulmann and Gayer (2000) classify these faults as dextral shear zones. The fact, they are strike slip faults confirm the inclination of these faults, varying around $90^{\circ}$. According to Grygar (2001), it is a paired element of the conjugated dislocation system oriented towards N-S. Shear zones oriented NW-SE are dominant there where majority of tension was released. Faults and joint systems oriented NNW-SSE and N-S are tensional dislocations generated within parallel shear zones of the dominant system (NW-SE). The mining maps function as evidence (see concept of on-surface fault courses created from mining maps Fig. 4). The course of these faults (N-S) is mostly interrupted by faults oriented NE-SW. The opinion of Grygar (2001) on the conjugated system is supported by higher occurrence of tensional dislocations in both conjugated directions (NNW-SSE and N-S) seen on rose diagrams of joint systems and lower occurrence of NW-SE oriented faults seen on rose diagrams of faults.

The dominant system oriented NW-SE (so-called Sudeten direction) combined with conjugated tensional dislocations creates areas of weakness of the rock massif. These areas are engaged by drainage network. Earlier morphotectonic studies of the entire Moravian-Silesian region (Jelínek, 2008) show that the majority of NW-SE oriented valleys are interconnected by morpholineaments corresponding to brittle tectonics oriented N-S and NNW-SSE. Grygar and Jelínek (2003) associate their actual geodynamic significance with Miocene dextral movement rejuvenation on the faults of Sudeten and Elbe system. As a result of thrusting nappe of the Outer Carpathian over the foreland of the Bohemian Massif from the south-east, these faults underwent a significant neoid rejuvenation. From the perspective of dynamics of Alpine stress field, with maximum compressive stress oriented NNW-SSE, these faults came in the OuterCarpathian foreland sheets into position of radial transtensional faults, conjugated with N-S systems of the Outer-Carpathian arc orogeny (Grygar, Jelínek, 2003).

The last and least manifested system in morphology is the system of the E-W direction. According to Rambousek, et al. (2004) this direction is associated to final stage of Variscan deformation and is represented by the joint systems with dominant jointing oriented E-W. This, however, contradicts the results of the structural analysis. Rose diagrams of joint systems show minimal occurrence in this direction (Fig. 3). Nevertheless, in the rose diagrams of faults this direction is ranked on the second place by occurrence (Fig. 3). On mining maps these faults interconnect the faults oriented NE-SW (Fig. 4). These could be the tensional faults arisen at the same time as dextral shear zones in the NE-SW direction. However, convincing evidence is scarce. 
Table 2 Summary of similarity results of individual morpholineaments with documented faults.

\begin{tabular}{|c|c|c|c|c|c|c|c|c|c|c|}
\hline \multicolumn{3}{|c|}{ Faults } & \multicolumn{7}{|c|}{ Morpholineaments } & \multirow[b]{2}{*}{ 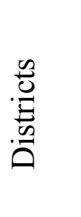 } \\
\hline No. & $\begin{array}{l}\text { Length } \\
{[\mathrm{m}]}\end{array}$ & $\begin{array}{c}\text { Azimuth } \\
\text { (average) } \\
\left.{ }^{\circ}\right]\end{array}$ & No. & $\begin{array}{l}\text { Length } \\
{[\mathrm{m}]}\end{array}$ & $\begin{array}{c}\text { Azimuth } \\
\text { (average) } \\
{\left[^{\circ}\right]}\end{array}$ & $\begin{array}{c}\text { Azimuth } \\
\text { deviation } \\
{\left[^{\circ}\right]}\end{array}$ & $\begin{array}{l}\text { LMB } \\
{[\mathrm{m}]}\end{array}$ & $\begin{array}{c}\mathrm{LMB} / \mathrm{LM} \\
{[\%]}\end{array}$ & $\begin{array}{c}\mathrm{LMB} / \mathrm{FL} \\
{[\%]}\end{array}$ & \\
\hline $1-\mathrm{ZH}$ & 430 & 34 & 1-HS & 1842 & 30 & 4 & 430 & 23 & 100 & \multirow{4}{*}{ 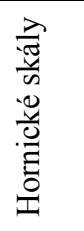 } \\
\hline $6-\mathrm{ZH}$ & 360 & 29 & 3-HS & 555 & 28 & 1 & 333 & 60 & 93 & \\
\hline $8-\mathrm{ZH}$ & 274 & 65 & 2-HS & 367 & 65 & 0 & 274 & 74 & 100 & \\
\hline $14-\mathrm{ZH}$ & 163 & 48 & 5-HS & 150 & 48 & 0 & 146 & 97 & 90 & \\
\hline $13-W$ & 367 & 45 & $1-\mathrm{M}$ & 2491 & 46 & 1 & 367 & 15 & 100 & \multirow{2}{*}{ 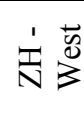 } \\
\hline $2-W$ & 225 & 41 & $3-\mathrm{M}$ & 1403 & 38 & 3 & 140 & 10 & 62 & \\
\hline 13 & 802 & 23 & 5 & 1273 & 23 & 0 & 667 & 52 & 83 & \multirow{16}{*}{ 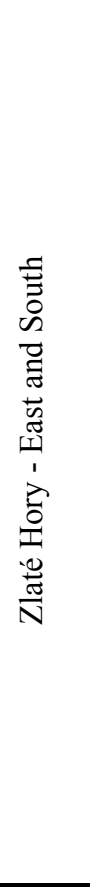 } \\
\hline 20 & 1102 & 23 & 7 & 1444 & 23 & 0 & 840 & 58 & 76 & \\
\hline 24 & 1192 & 26 & 8 & 1071 & 27 & 1 & 510 & 48 & 43 & \\
\hline 32 & 148 & 87 & 9 & 130 & 87 & 0 & 120 & 93 & 81 & \\
\hline 7 & 198 & 83 & 10 & 261 & 83 & 0 & 106 & 40 & 53 & \\
\hline 44 & 65 & 85 & 11 & 65 & 85 & 0 & 65 & 100 & 100 & \\
\hline 18 & 779 & 26 & 12 & 929 & 25 & 1 & 614 & 66 & 79 & \\
\hline 62 & 156 & 74 & 14 & 140 & 74 & 0 & 140 & 100 & 89 & \\
\hline 34 & 771 & 32 & 15 & 1099 & 31 & 1 & 472 & 43 & 61 & \\
\hline 52 & 601 & 48 & 16 & 737 & 49 & 1 & 461 & 62 & 77 & \\
\hline 58 & 695 & 25 & 18 & 856 & 25 & 0 & 695 & 81 & 100 & \\
\hline 9 & 770 & 26 & 19 & 1005 & 26 & 0 & 770 & 77 & 100 & \\
\hline 28 & 877 & 30 & 20 & 1431 & 29 & 1 & 877 & 61 & 100 & \\
\hline 51 & 72 & 66 & 25 & 267 & 64 & 2 & 66 & 25 & 92 & \\
\hline 40 & 163 & 72 & 26 & 260 & 71 & 1 & 163 & 63 & 100 & \\
\hline 3 & 229 & 78 & 31 & 187 & 78 & 0 & 126 & 67 & 55 & \\
\hline & & & & & & & & Average & 83 & \\
\hline
\end{tabular}

\section{RESULTS AND DISCUSSION}

The verification of the similarity of the inferred morpholineaments network with documented faults was carried out in all the exploitation areas mentioned above. By using the created procedure, the morpholineaments belong to the buffer zone of some of the documented fault, were searched. Twenty two concordant morpholineaments that fit the criterion of $20 \mathrm{~m}$ buffer width were identified in total (Table 2). The selected numerical procedure for evaluation of the validity of morpholineaments network (Table 2) was based on percentage ratio of morpholineaments length inside the buffer of given fault to the total length of the fault. For individual morpholineaments, the value of this parameter ranges from 43 to $100 \%$. The highest validity is showed in the area $\mathrm{ZH}$-Hornické skály. There were found 4 morpholineaments with the match (ratio LMB / FL) higher than $90 \%$. In the $\mathrm{ZH}-$ East and South, 9 out of 16 matching over $80 \%$ were found, 5 of these of $100 \%$ concordance. In all of the exploitation areas, the average value is $83 \%$ (Table 2). This result depends on the buffer width setting and on the accuracy of the generated morpholineaments network.

As we can see from Figure 5, the best concordance of both networks is between directional lines oriented from NE-SW and N-S up to NNW-SSE (see Fig. 5). Fault course of the N-S direction is interrupted by the direction of NE-SW, which is much numerous. The NW-SE direction is manifested mainly in the exploitation areas of $\mathrm{ZH}-$ West and $\mathrm{ZH}$ Hornické skály.

The accuracy of the created morpholineaments network depends on the chosen morphometric methods of MSA and the DEM accuracy and scale. The used MSA methodology has been created and verified (Jelínek and Grygar, 2002; Jelínek et al., 2009; Jelínek et al., 2011) especially for the purpose of identification of brittle failure of the rock massif. Within compilation of the methodology and selection 


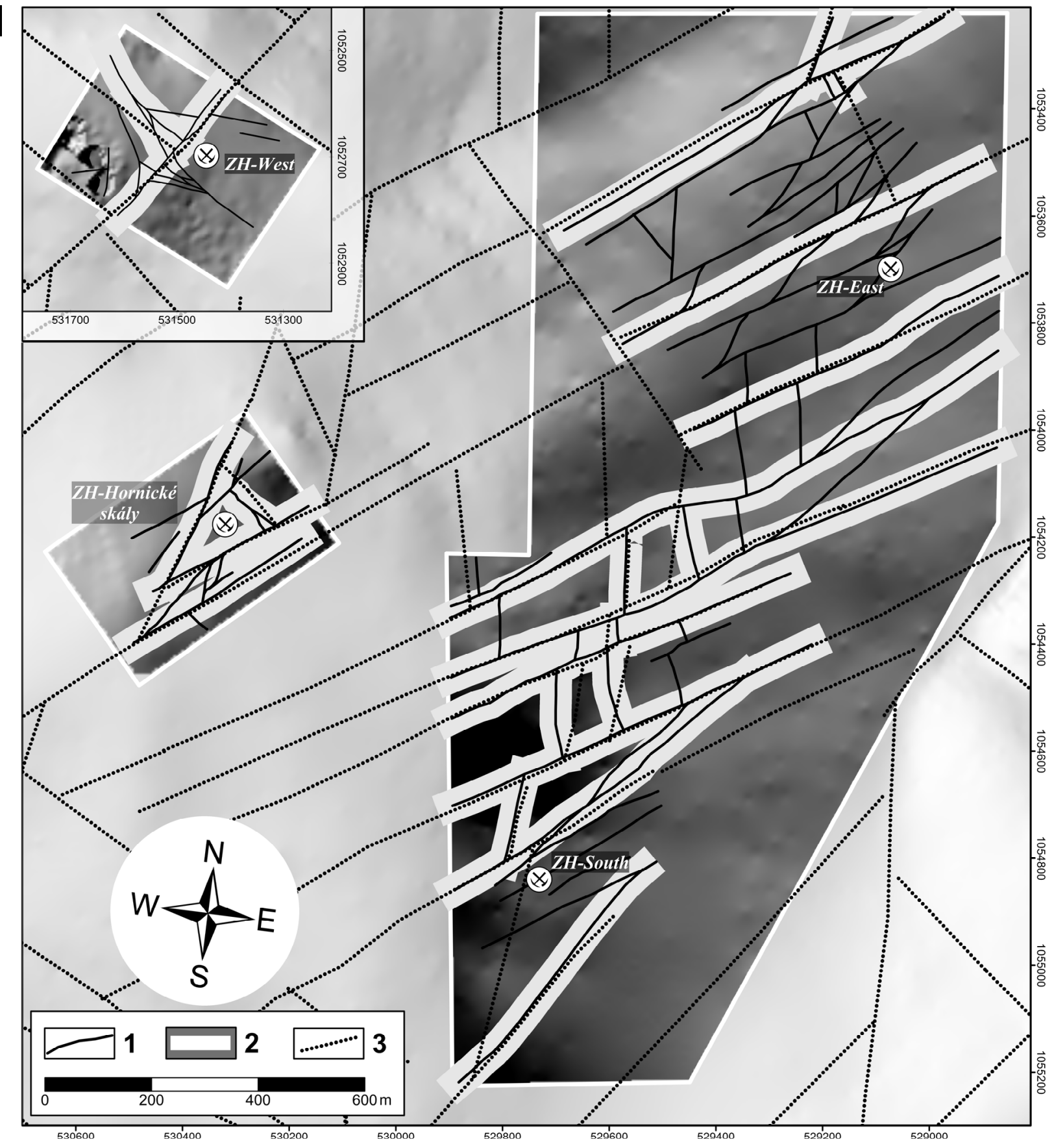

Fig. 5 Shaded relief map of exploitation areas with graphical depicting the similarity of morpholineaments and geologically verified faults in mines.

Legend: 1 - geologically verified fault; 2 - fault buffer containing a morpholineament; 3 morphological lineament.

of suitable morphometric methods the lithological character of the study area was taken into account. An attention in the DEM interpretation phase was focused primarily on surface curvature changes.

The chosen validity evaluation methodology of morpholineaments network takes into account different detailed features of the two compared networks. The geologically documented fault network was compiled on the basis of mining maps of the 1:500 scale. The morpholineaments network was compiled on the basis of the MSA from DEM with accuracy corresponding to the topographic maps of the 1:10 000 scale. It is obvious that mining maps show much more faults than we can identify in the DEM of smaller scale by MSA.

If we choose a methodology for evaluation of validity of morpholineaments network based on percentage of the length of morpholineaments matching with the fault buffers, the resulting validity is less than $60 \%$. If we compared the ratio of 
morpholineaments length in buffers with the length of all documented faults in the testing area, the result would be $51 \%$. However, these comparisons might be incorrect since the details level of the two compared networks is different and the documented faults are depicted on the maps only within the mining works without extrapolation beyond the exploitation areas. Last but not least important role in identification of morpholineaments by the MSA plays the geological evolution of the region. The area of interest consists mainly of crystalline rocks. The genesis of these rocks as well as the genesis of most faults is associated with the Variscan orogeny and the post Variscan rejuvenation. At that time the formed relief was until Paleogene, significantly planated. The current morphologically distinct relief was formed in Miocene by uplifting of the Jesenik horst structure caused by overthrusting of the Western Carpathians on the Bohemian massif (Grygar and Jelínek, 2003). Many of the old Paleozoic structures were rejuvenated and they significantly participate in the present-day morphology. However, joint systems and cleavage zones are more manifested in relief than the fault structures. Therefore, not all of the identified morpholineaments can be directly considered as faults without further geological exploration.

\section{CONCLUSIONS}

The morphostructural analysis was used in the brittle failure study of the studied crystalline rock massif. Morphometric methods of MSA used in this work (slope, aspect, first directional derivative, gradient operator and combination of altitude and shaded relief) were selected with respect to the facile software availability, frequent common users' usage of the mentioned software and to the nature of the available data. By the created software SROV_TEKT and by the described evaluation procedure, the validity of the established morpholineaments network created by us was set to $83 \%$. If we choose a less objective method, the length percentage of morpholineaments extending into buffers of faults, the resulting validity is less than $60 \%$. All these results can be considered to be satisfactory because the morphostructural analysis is usually applied in the preliminary survey. Knowledge of an approximate position and course of morpholineament will facilitate the planning of consequent survey work. This will save financial funds otherwise spent on less effectively conducted survey (wrong localization of the survey work, wrong direction of the electrical resistance profiling or of the seismic profiling, etc.)

The aim of this paper was to point out the benefits of the MSA in the preliminary survey, and at same time to indicate possible imprecision in the implementation of geotectonic studies based only on the analysis of morpholineaments. As the results of this study have shown, it is not possible to consider all morpholineaments identified by the morphostructural analysis to be faults.

\section{ACKNOWLEDGEMENTS}

This research has been carried out within the project GA CR 105/09/1090 financed by the Grant Agency of the Czech Republic and the project Institute of clean technologies for mining and utilization of raw materials for energy use, reg. no. CZ.1.05/2.1.00/03.0082 supported by Research and Development for Innovations Operational Program financed by Structural Funds of European Union and from the means of state budget of the Czech Republic.

\section{REFERENCES}

Arzhannikova, A.V., Arzhannikov, S.G., Jolivet, M., Vassalo, R. and Chauvet, A.: 2011, Morphotectonic analysis of Pliocene-Quaternary deformations in the southeast of the Eastern Sayan. Geotectonics, 45, No. 2, 142-156. DOI: 10.1134/S001685211101002X

Ahnert, F.: 1998, Introduction to Geomorphology, Arnold, London, $360 \mathrm{pp}$.

Bloom, A.L.: 1998, Geomorphology - A Systematic Analysis of Late Cenozoic Landforms, Prentice Hall Upper Saddle River, New Jersey, USA, 482 pp.

Cadoppi, P., Giardino, M., Perrone, G. and Tallone, S.: 2007, Litho-structural control, morphotectonics, and deep-seated gravitational deformations in the evolution of Alpine relief: A case study in the lower Susa Valley (Italian Western Alps). Quaternary International, 171-172, 143-159. DOI: $10.1016 /$ j.quaint.2006.10.015

Caiazzo, C., Ascione, A. and Cinque, A.: 2006, Late Tertiary-Quaternary tectonics of the Southern Apennines (Italy): New evidences from the Tyrrhenian slope. Tectonophysics, 421, 23-51. DOI: $10.1016 /$ j.tecto.2006.04.011

Cotilla, M.O., Córdoba, D. and Herraiz, M.: 2007, A morhotectonic study of the Central System, Iberian Peninsula. Russian Geology and Geophysics, 48, 378387. DOI: $10.1016 /$ j.rgg.2007.03.005

D'Alessandro, L., Miccadei, E. and Piacentini, T.: 2008, Morphotectonic study of the lower Sangro River valley (Abruzzi, Central Italy). Geomorphology, 102, 145-158. DOI: 10.1016/j.geomorph.2007.06.019

Delcaillau, B., Laville, E., Amhrar, M., Namous, M., Dugué, O. and Pedoja, K.: 2010, Quaternary evolution of the Marrakech High Atlas and morphotectonic evidence of activity along the Tizi N'Test Fault, Morocco. Geomorphology, 118, 262-279. DOI: 10.1016/j.geomorph.2010.01.006

Demek, J.: 1987, Mountains and lowlands: Geographic lexicon of ČSR, Academia, Praha, 584 pp., (in Czech).

Formento-Trigilio, M.L., Burbank, D.W., Nicol, A., Shulmeister, J. and Rieser, U.: 2002, River response to an active fold-and-thrust belt in a convergent margin setting, North Island, New Zealand. Geomorphology, 49, 125-152. DOI: 10.1016/S0169-555X(02)00167-8

Gioia, D., Schiattarella, M., Mattei, M. and Nico, G.: 2011, Quantitative morphotectonics of the Pliocene to Quaternary Auletta basin, southern Italy. Geomorphology, 134, 326-343. DOI: 10.1016/j.geomorph.2011.07.009

Grohmann, C.H., Riccomini, C. and Alves, F.M.: 2007, SRTM-based morphotectonic analysis of the Pocos de Caldas Alkaline Massif, southeastern Brazil. Computers and Geoscience, 33, 10-19. DOI: $10.1016 /$ j.cageo.2006.05.002 
Grygar, R.: 1987, Contribution to the knowledge of Paleozoic tectonic styles - northern part of the Jeseniky (in Czech). Sborník Jeseníky, 1-14.

Grygar, R.: 1992, Kinematics of Lugosilesian orocline accretion wedge in relation to the brunovistulian forland. Sborník VŠB Ostrava, 37, No. 1, 49-72.

Grygar, R. and Kalenda, F.: 1992, The structural and stratigraphic aspects of the mineralization controle of the Zlaté hory ore district. Sborník VŠB Ostrava, 37, No. 1, 73-78.

Grygar, R. and Vavro, M.: 1995, Evolution of Lugosilesian Orocline (North-eastern periphery of the Bohemian Massif): Kinematics of Variscan deformation. Journal of the Czech Geological Society, 40, No. 1-2, 65-90.

Grygar, R.: 2001, Structural evolution of the Upper Silesian Basin. In. Müller P. et al.: Comprehensive evaluation of the program CBM. MS ČGS, MS Geofond ČR, (in Czech).

Grygar, R. and Jelínek, J.: 2003, The Upper Morava and Nysa Pull-apart Grabens - The evidence of neotectonic dextral transtension on the Sudetic Faults System. Acta Montana IRSM AS CR, No. 24 (131), 51-59.

Jayko, A.S.: 1997, Investigation of the San Bruno Fault Near the Proposed Extension of the Bay Area Rapid Transit Line from Colma to San Francisco International Airport, San Mateo Country, California. Repost of U.S. Geological Survey, 73 pp.

Jelínek, J. and Grygar, R.: 2002, Interaction between Alpine and Variscan Orogeny on the basis of study digital elevation models - Moravosilesian Area. Acta Montana IRSM AS CR, No. 20 (124), 51-55.

Jelínek, J.: 2004, Morphostructural analysis as a right method of geology structure studying applied at representative Moravosilesian area. Sbor. věd. prac. VŠB-TU Ostrava, 50, No. 1, 41-55, (in Czech).

Jelínek, J.: 2008, Morphotectonic analysis of digital relief model - A suitable means of searching for zones of rock mass brittle failure. GeoScience Engineering, LIV, 1-14.

Jelínek, J., Staněk, F., Honěk, J. and Hoňková, K.: 2009, Modelling of seam bases and tectonic faulting of Dubňany and Kyjov lignite seams. Acta Montanistica Slovaca, 14, No. 1, 62-74

Jelínek, J., Staněk, F., Vizi, L. and Honěk, J.: 2011, Evolution of lignite seams within the South Moravian Lignite Coalfield based on certain qualitative data. International Journal of Coal Geology, 87, 237-252. DOI: 10.1016/j.coal.2011.06.017.

Jordan, G.: 2003, Morphotectonic analysis and tectonic interpretation of digital terrain data: a case study. Earth Surface Processes and Landforms, 28, 807-822.

Jordan, G., Csillag, G., Szucs, A. and Qvarfort, U.: 2003, Application of digital modelling and GIS methods for the morphotectonic investigation of the Kali Basin, Hungary. Z. Geomorph. N.F., 47, No. 2, 145-169.

Kokkalas, S. and Koukouvelas, I.K.: 2005, Fault-scarp degradation modeling in central Greece: The Kaparelli and Eliki faults (Gulf of Corinth) as a case study. Journal of Geodynamics, 40, 200-215. DOI: $10.1016 /$ j.jog.2005.07.006

Kukowski, N., Schillhorn, T., Huhn, K., Ulrich von Rad, Husen, S. and Flueh, E.R.: 2001, Morphotectonics and mechanics of the central Makran accretionary wedge off Pakistan. Marine Geology, 173, 1-19. DOI: $10.1016 / \mathrm{S} 0025-3227(00) 00167-5$

Kukowski, N., Hampel, A., Hoth, S. and Bialas, J.: 2008, Morphotectonic and morphometric analysis of the
Nazca plate and the adjacent offshore Peruvian continental slope - Implications for submarine landscape evolution. Marine Geology, 254, 107-120. DOI: 10.1016/j.margeo.2008.05.017

Marschalko, M., Yilmaz, I., Bednárik, M. and Kubečka, K.: 2011, Deformation of slopes as a cause of underground mining activities: three case studies from Ostrava-Karviná coal field (Czech Republic). Environmental Monitoring and Assessment, 1-25. DOI: $10.1007 / \mathrm{s} 10661-011-2453-4$

Maroukian, H., Gaki-Papanastassiou, K., Karymbalis, E., Vouvalidis, K., Pavlopoulos, K., Papanastassiou, D. and Albanakis, K.: 2008, Morphotectonic control on drainage network evolution in the Perachora Peninsula, Greece. Geomorphology, 102, 81-92. DOI: 10.1016/j.geomorph.2007.07.021

Masoud, A.A. and Koike, K.: 2011, Morphotectonics inferred from the analysis of topographic lineaments auto-detected drom DEMs: Application and validation for the Sinai Peninsula, Egypt. Tectonophysics, 510, 291-308. DOI: 10.1016/j.tecto.2011.07.010

Miliaresis, G.Ch.: 2001, Geomorphometric mapping of Zagros Ranges at regional scale. Computers and Geosciences, 27, 775-786. DOI: 10.1016/S0098-3004(00)00168-0

Minár, J., Bielik, M., Kováč, M., Plašienka, D., Barka, I., Stankoviansky, M. and Zeyen, H.: 2011, New morphostructural subdivision of the Western Carpathians: An approach integrating geodynamics into tergeted morfometric analysis. Tectonophysics, 502, 158-174. DOI: 10.1016/j.tecto.2010.04.003

Mumipour, M. and Nejad, H.T.: 2011, Tectonics geomophology setting of Khayiz Anticline derived from GIS processing, Zagros Mountains, Iran. Asian Journal of Earth Sciences, 4, No. 3, 171-182.

Norini, G., Groppelli, G., Capra, L. and Beni, E.: 2004, Morfological analysis of Nevado de Toluca volcano (Mexico): new insights into the structure and evolution of an andesitic to dacitic stratovolcano. Geomorphology, 62, 47-61.

Orel, P.: 1975, Variscan Paleozoic tectonic style of the western part of the Bohemian Massif Jeseník block. Výzkumná práce ÚÚG, 8, 7-23, (in Czech).

Pánek, T.: 2004, Morphotectonics of the Silesian and Magura nappe in the area of the Western Beskydy Mts. (Czech Republic). Geografický časopis, 56, 315335, (in Czech).

Pánek, T., Hradecký, J., Minár, J., Hungr, O. and Dušek, R.: 2009, Late Holocene catastrophic slope collapse affected by deep-seated gravitational deformation in flysch: Ropice Mountain, Czech Republic. Geomorphology, 103, 414-429. DOI: 10.1016/j.geomorph.2008.07.012

Rambousek, P., Grygárek, J. and Večeřa, J.: 2004, Mining and Environmental evaluation of the Zlaté Hory district after the mining and processing of ores and prognosis of its future development. Výzkumná zpráva projektu GA105/02/0692, Praha, 100 pp., (in Czech).

Rehak, K., Strecker, M.R. and Echtler, H.P.: 2008, Morphotectonic segmentation of an active forearc, $37^{\circ}-41^{\circ} \mathrm{S}$, Chile. Geomorphology, 94, 98-116. DOI: 10.1016/j.geomorph.2007.05.002

Ritter, D.F., Kochel, R.C. and Miller, J.R.: 2002, Process geomorphology - fourth edition. New York, The McGraw-Hill Companyes, 560 pp. 
Ruszkiczay-Rüdiger, Z., Fodor, L., Horváth, E. and Telbisz, T.: 2009, Discrimination of fluvial, eolian and neotectonic features in a low hilly landscape: A DEMbased morphotectonic analysis in the Central Pannonian Basin, Hungary. Geomorphology, 104, 203-217. DOI: 10.1016/j.geomorph.2008.08.014

Seta, M.D., Monte, M.D., Fredi, P., Miccadei, E., Nesci, O., Pambianchi, G., Piacentini, T. and Troiani, F.: 2008, Morphotectonic evolution of the Adriatic piedmont of the Apennines: An advancement in the knowledge of the Marche-Abruzzo border area. Geomorphology, 102, 119-129.

DOI: 10.1016/j.geomorph.2007.06.018

Scheidegger, A.E.: 2001, Surface joint systems, tectonic stresses and geomorphology: a reconciliation of conflicting observations. Geomorphology, 38, 213219. DOI: $10.1016 / \mathrm{S} 0169-555 \mathrm{X}(00) 00091-\mathrm{X}$

Schulmann, K. and Gayer, R.: 2000, A model for a noctinental accretionary wedge developed by oblique collision: the NE Bohemian Massif. Journal of the Geological Society, 157, 401-416.

Staněk, F., Jelínek, J., Honěk, J. and Hoňková, K.: 2008, Modelling of the Dubñany lignite seam base in the Moravian central depression (the Czech part of the Vienna basin). GeoScience Engineering, 54, No. 3, $14-25$.

Sung, Q. and Chen, Y.: 2004, Self-affinity dimensions of topography and its implications in morphotectonics: an example from Taiwan. Geomorphology, 62, 181198. DOI: $10.1016 /$ j.geomorph.2004.02.012

Štěpančíková, P., Stemberk, J., Vilímek, V. and Košták, B.: 2008, Neotectonic development of drainage networks in the East Sudeten Mountains and monitoring of recent fault displacements (Czech Republic). Geomorphology, 102, 68-80.

DOI: 10.1016/j.geomorph.2007.06.016

Večeřa, J.: 1999, Analysis of surface shapes generated by mining Au. Miner. slov., 31, 3-4, 309-312, (in Czech).

Zuchiewicz, W.: 1998, Quaternary tectonics of the Outer West Carpathians, Poland. Tectonophysics, 297, 121132.

Zuchiewicz, W.: 2009, Neotectonics of the Polish Carpathians in the light of geomorphic studies: a state of the art. Acta Geodyn. Geomater., 6, No. 3 (155), 291-308.

Zuchiewicz, W.: 2011, Pleistocene tectonic activity of the Polish Western Carpathians: Insights from fluvial terraces. Acta Geodyn. Geomater., 8, No. 3 (163), $197-224$ 